\title{
INTERACTION BETWEEN KARST, WATER AND AGRICULTURE OVER THE CLIMATIC GRADIENT OF ISRAEL
}

\author{
Amos Frumkin
}

\begin{abstract}
The dry climate of Israel and the karstic nature of its rocks have always imposed human innovation for utilisation of water resources and agriculture. Large perennial karst springs are available only in the lowlands, but sophisticated water supply systems were built both in the lowland and highland regions. Marl layers interbedded within carbonates give rise to local perched springs and allow terrace construction. Deforestation has taken place for some 4000 years, causing intense soil erosion, but terraces have reduced this impact.
\end{abstract}

KEY WORDS: fluviokarst, karst springs, east Mediterranean, water supply, deforestation, human impact.

\section{Introduction}

Israel displays a gradient of karst features from the intensive karstification of Lebanon in the north to practically no karst in the southern Negev desert.

This is attributed mainly to the climatic gradient from alpine-Mediterranean climate in the Lebanon - Hermon mountains in the north, with precipitation $>1000$ $\mathrm{mm}$ /year, to the extremely arid southern Negev, with $<50 \mathrm{~mm} /$ year. Another factor is the southward decrease in carbonates/clastics ratio of the phanerozoic stratigraphic column, due to the increasing distance from the Tethys Sea which deposited the carbonates.

Carbonate rocks crop-out in some $75 \%$ of the hilly regions of Israel. They are predominantly of Jurassic to Eocene age. However, much of the carbonates contains marls which inhibit extensive karst development, promoting the dominance of fluviokarst features.

Israel is geographically a part of the Fertile Crescent, where several ancient civilisations practised agriculture and utilisation of water resources during their evolution. Most of the Fertile Crescent enjoys an arid to semi-arid climate, in which potential evaporation exceeds precipitation. Such conditions pose a challenge for agriculture and human use of water, especially in karst terrains.

Both Egypt at the south-western part of the Fertile Crescent and Mesopotamia at the north-east relied heavily on large rivers- the Nile, Euphrates and Tigris, deriving their waters from distant, wetter regions. A centralized power was needed in these regions to develop the water resource and regulate its use. However, in Israel a basic precondition is the absence of allogenic sources of water, and the availability of some local karstic sources. Thus the scarce water resources might have limited the deve- 
lopment of ancient (e.g. Bronze Age) large agricultural economies and centralized civilizations. During more recent periods the special natural conditions of Israel seem to have promoted diverse hydrogeologic and engineering solutions which overcame the scarcity of water.

Many settlements in Israel depended heavily on rain and runoff collection during most historical periods. Utilization of more reliable supply from perennial karst springs, rivers and ground water depended on available technology as well as on the knowledge of hydrogeologic and topographic conditions.

\section{Climate, water and people}

The present climate of the northern half of Israel is Mediterranean to semi-arid, while the southern part is semi-arid to hyper-arid. The summer, June to October, is warm and dry, while most precipitation falls during the winter.

Some authors have suggested that the pattern of human habitation was determined mainly by climate (e.g. Huntington, 1911; Issar, 1990). This assumption should be checked by natural proxy paleoclimatic evidence which is as independent as possible from human interference. Several lines of evidence indicate that the last considerably moister period was the Early Bronze, with moistest conditions $~ 5000$ calendar years B. P. (Frumkin et al., 1994). The highly developed urban civilization of the Early Bronze age which developed even in the arid regions around the southern Dead Sea (Arad, Bab edh-Dhra) apparently lacked sophisticated water supply systems. Their development is rather attributed to the moister climate, and their destruction is associated with abrupt climatic degradation. About 4500 calendar years B. P. climate indeed deteriorated rapidly towards the drier regime prevailing since the Middle Bronze age until today (Frumkin et al., 1991). The dry climate of the last 4500 years was however interrupted by some slightly moister episodes as indicated by speleothems and other proxies (Frumkin et al., 1999; Issar et al., 1991).

Rainfall in Israel is typically in the form of high-intensity showers. Therefore the impact of rain drops is large, causing intense erosion of soil, unless the soil is protected by vegetative cover.

\section{Geology of karst regions}

The rocks exposed in Israel were mostly deposited in continental and marine environments during the Mesozoic and Cenozoic eras. Of these, the backbone of Israel's mountains consists mainly of marine sediments of Albian to Middle Eocene age. The country is located between the Mediterranean Sea and its predecessor Tethys Ocean to the north-west, and the Arabo-Nubian shield to the south-west. The variations of sediments in space and time were mostly determined by the relative positions of the sea, depositing biochemical sediments, and the continent, supplying terrigenous material. During the Cenomanian-Turonian age the common deposition environment was a wide shallow platform lagoon with barrier reefs isolating the lagoon from the open sea (Sass \& Bein, 1978). The resulting rock is mainly dolomi- 
te, interbedded with thin marl layers. Some deeper basins produced limestones and chalks. Reefs produced several massive permeable limestone bodies. Variable deposition rates could control the relative amounts of carbonates and clays within a particular bed. During the Senonian age deeper sea water environment gave rise to chalky deposits, while Eocene age sediments are mainly limestone in some regions and chalk in others.

Regional uplift followed the Middle Eocene, terminating the continuous marine deposition. Since then the highlands of Israel underwent continuous erosion, mainly karstic and fluvial (Frumkin, 1993). The Late Cenozoic northward movement of the Arabian plate formed the Dead Sea Rift, producing a deep depression with inland drainage since $\sim 6$ million years ago (Steinitz \& Bartov, 1991). The rifting, as well as Quaternary uplift of the backbone mountains and associated accelerated erosion sculptures the recent topography of the country, while Neogene and Quaternary sediments fill the valleys. Volcanic eruptions have overlain the Golan Heights and parts of Eastern Galilee with relatively flat basalt sheets.

Consequently, in most of the mountain regions karstic rocks crop-out, and their degree of karstification depends mainly on local climate, topography and the amount of clay within the carbonate rocks.

The most common soils on karstic hilly terrains of Israel are terra-rossa and rendzina (Dan et al., 1976), derived from allogenic aeolian dust and residue of local rocks (Yaalon \& Ganor, 1973). Grumusols with abundant clay are common in karst depressions.

The major carbonate karst regions of Israel are briefly reviewed below (Fig. $1)$.

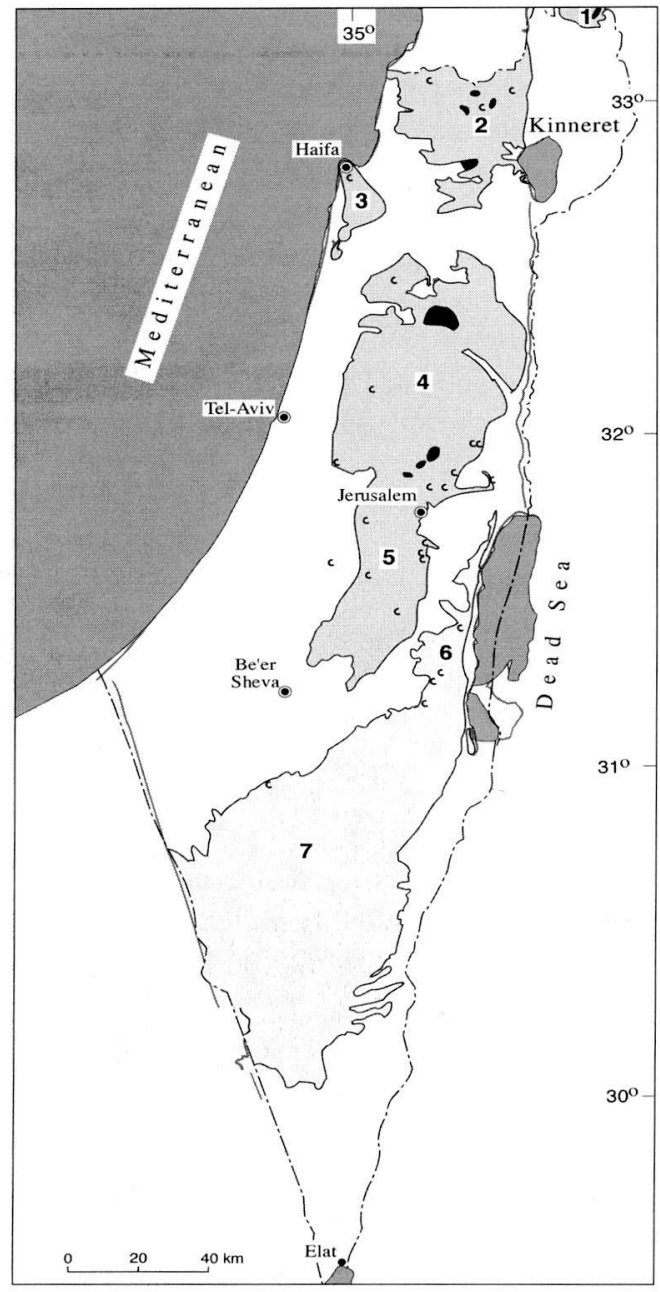

Fig. 1 - A map showing the carbonate karst regions of Israel: (1) Hermon; (2) Galil; (3) Carmel; (4) Shomeron; (5) Judea; (6) Judean Desert; (7) Negev Desert. Black color indicates karst depressions with internal drainage. Dark gray - Mediterranean type karst regions with intensive agriculture. Light gray arid zone with carbonate rocks, few karst features and limited agriculture. Caves longer than $200 \mathrm{~m}$ in carbonate rocks are shown by semicircles. 


\subsection{Hermon}

The higher part of Mount Hermon, on the northern end of Israel, displays distinctive alpine karst features. The elevation within Israel's border reaches $2220 \mathrm{~m}$, and snow covers the higher parts several months a year. Massive Jurassic limestone, several hundred meters thick, gives rise to developed holokarst with doline fields and poljes. Agriculture was practiced in the past up to $\sim 1500 \mathrm{~m}$ a.s.l. The Jordan river emerges from large springs at the foot of Mount Hermon which lacks perennial springs within its elevated parts in spite of high precipitation $(>1300 \mathrm{~mm} / \mathrm{y})$.

\subsection{Galil}

The Galil mountains is the major karst region of northern Israel, developed on Cretaceous to Eocene carbonates. Mediterranean fluviokarst terrain is common, while the upper Galil, especially around Mount Meron, displays some mature karstified areas (Gerson, 1974). Of these, Mount Peqi'in is notable for its developed doline karst landforms with highest density of limestone vadose shafts in Israel. Two ponors drain large karst areas: Me'arat $\mathrm{Pa}$ 'ar, in the bottom of a large doline, and Zomet Meron sink.

\subsection{Carmel}

The Carmel ridge is built mainly of Upper Cretaceous carbonates.

Fluviokarst is common, while karstic closed depressions are rare. A major active fault along the north-eastern edge of the ridge seems to inhibit karst development on this side.

\subsection{Shomeron}

Karst landforms in Shomeron appear on Jurassic to Neogene carbonate rocks. The Ram'alla anticline at eastern Shomeron is dissected by large transversal faults. Large caves appear mainly on its southern part, which is structurally similar to the Judean mountains.

The limited outcrop of Jurassic limestone displays extensive surface karren features, such as rillenkarren. Most regional karst features appear on Cretaceous to Eocene limestones and dolomites. The Eocene carbonates of the northern Shomeron syncline serves as a major karst aquifer of Bet-She'an valley and Shekhem region. This region displays the largest tectonokarst feature in Israel - the Sanur polje.

Karst landforms appear rarely in Tertiary conglomerates of eastern Shomeron.

\subsection{Judea}

Karst features appear here on Cretaceous to Eocene carbonates. Much of the upper erosion surface of Judean Mountains was formed by karst denudation (Frumkin, 1993) . Fluviokarst is most common, but north of Jerusalem there are some areas of internal karst drainage (Fig. 2), and also a doline field with 12 known vadose shaft systems (Frumkin, 1986). Lack of major faults has promoted the development of long and stable subsurface flow routes in the phreatic zone, allowing the 


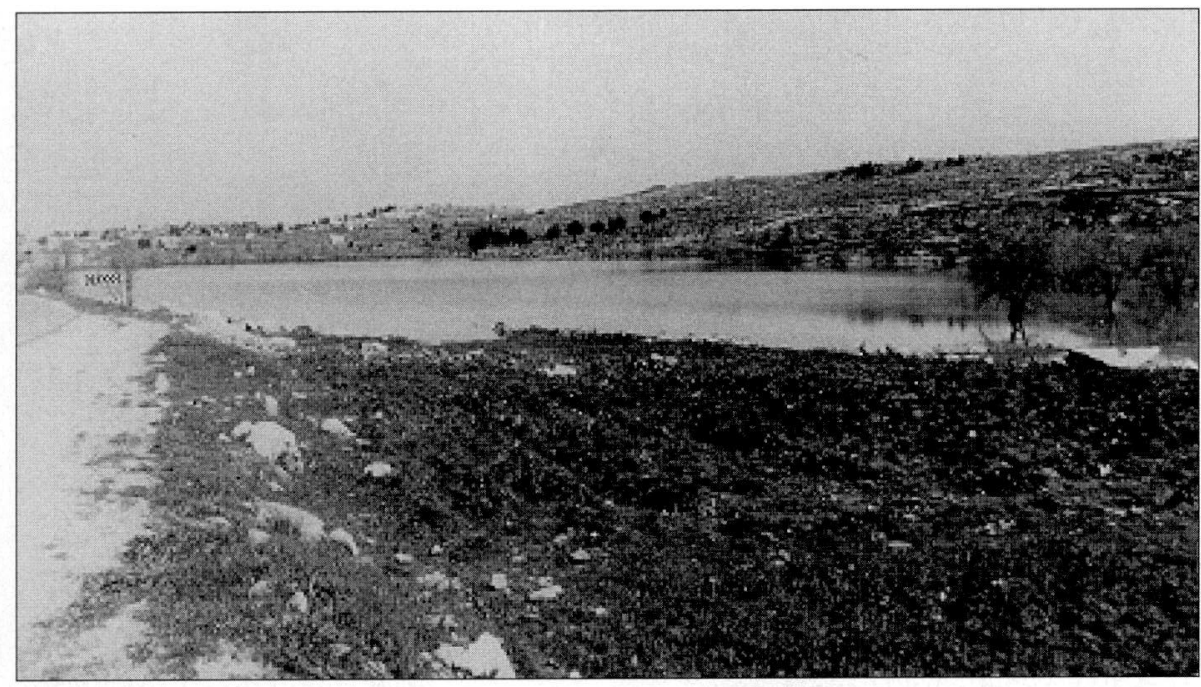

Fig. 2 - Karst depression $0.5 \mathrm{~km}$ long filled with water after winter rainfall (Beitunia, Judea). It is cultivated for vegetables and fruits.

development of the largest and most abundant limestone caves in Israel.

\subsection{Negev and Judean deserts}

These regions are arid, with precipitation lower than $200 \mathrm{~mm} / \mathrm{year}$. Therefore active karst processes are mostly limited to the micro scale, and agriculture is limited too. Judean desert is a product of rain-shadow east of Judean mountains. These mountains (precipitation of up to $600 \mathrm{~mm} /$ year) are the input zone of ground water discharging along the Dead Sea. Such circulation has probably formed the relict phreatic caves found in Turonian limestone west of the Dead Sea. Unlike Judean desert, the Negev is part of the global Saharan arid belt. Water was probably insufficient for extensive karst development even during humid phases of the Pleistocene, but agriculture was practiced in several periods.

\section{Ground water and water supply}

Water is recharged in the carbonate rock outcrops of the mountain ranges, and discharge to major springs along the foothills regions: (1) in the west: Kabri springs, Taninim springs, and Yarqon springs; (2) in the east: the Bet-She'an, Jordan valley, and Dead Sea springs. Most of these springs get their water from large underground karst catchments, allowing abundant water supply the whole year round.

Within the mountain ranges proper, however, water is scarce, being the most limited resource for agriculture. Two types of rocks are distinguished here: (1) Pure karstic rocks, with $<10 \%$ insoluble impurities form highly karstic permeable mountain ridges which deliver practically all infiltrated water down towards the regional aqui- 
fer (Ford \& Williams, 1989). In this type of terrain water resurgence typically occurs at the foot of the mountains rather than within the elevated region. (2) Where marls and chalk are incorporated within the karst rocks, they tend to obstruct water flow locally, forming aquicludes. Local aquifers are perched above these layers, giving rise to abundant springs, discharging at the contact between the karstic rock and the underlying impermeable layer. The ancient population of the Judean Mountains (and to a lesser degree, other regions) used these water sources, in addition to rain water, for agriculture. However, most of the mountain springs are characterized by low discharge ( $<1$ litre/second) due to their relatively small catchments. Moreover, the relatively fast flow via karstic conduits and the small catchment area cause discharge to fluctuate heavily, both seasonally and annually in direct relation to precipitation.

As population increased, water supply engineers had to find ways to extract more water from the limited ground water resources of the mountain aquifers. Several solutions were utilized:

1) Large volume water storage. Reservoirs were used for retaining water from night to day, and for dry seasons.

2) Increasing the discharge of mountain springs by excavation of short sub-horizontal tunnels. This method has been used in Israel continuously for thousands of years. Excavation usually began from a spring into the mountain along the fissure supplying the water (Ron, 1966). The method was in use since the Iron Age when the monumental sub-horizontal water tunnel of El-Jib spring had probably been excavated (Pritchard, 1961). In some cases the water engineers incorporated natural karstic caves within their tunnel systems, increasing their yield with relatively little effort, e.g. Ein Wadi el-Biar of the Jerusalem water supply (Miron \& Frumkin, 1986).

3) Long tunnels were excavated during the Roman period along ground water-bearing rock formations to collect their water. Shafts were used as initial points of excavation as well as for air introduction and maintenance. These tunnel systems were excavated along stream valleys, several meters below the stream channel level. This was feasible only where an aquifer is close enough to the surface, an uncommon feature in the mountains of Israel. Two major systems using this technique are known in Israel: (a) The Upper Biar tunnel, $2.8 \mathrm{~km}$ long, extracting water from Cenomanian dolomitic-marly rock for the Jerusalem water supply system (Tsuk et al., 1986). (b) The upper Nahal Taninim tunnels, $>6 \mathrm{~km}$ long, utilized an Eocene chalky aquifer (Sigelman \& Ravek, 1993).

4) Qanat (Foggara) systems, widely known from Iran, were used along the arid parts of the Jordan Valley and the Arava, probably during the 7-8 century C.E. (Porath, 1987). They were designed to capture mountain aquifer water by a'mother well' before it becomes salinated within the rift valley deposits, and to convey the water to the surface through a moderately-inclined tunnel.

Local surface runoff stored in cisterns was a major water source in the whole 
country. In the desert this source becomes even more important . This source shares the insecurity of discontinuous supply during droughts, but it may suffer only small damage from extreme rain events due to the small catchment of each cistern.

The Negev desert has few permanent springs. Major spring sites like Kadesh Barne'a naturally attract human activity and water engineering. A more widespread way of using ground water in the Negev was digging vertical wells. This method takes advantage of the fact that much of the desert rain and runoff infiltrates through permeable surfaces or stream beds. The regional aquifer is shallow near the Mediterranean coast, becoming deeper further inland. This determined the depth of wells and the possibility to reach the water using available techniques.

In the mountain region of the Mediterranean zone agriculture depended heavily on rain. On the other hand the desert agriculture depended mostly on runoff harvesting which promoted engineering innovations.

\section{Deforestation and soil use}

Karst depressions of Israel are most easily cultivated, as their soils are commonly deep and fertile. These were used for farming at least since the Bronze Age. However, some depressions lack drainage (Fig. 2), and their hydromorphic conditions were unfavourable for agriculture until the 20th century, when most wetlands were drained and replaced by agriculture. Natural vegetation is almost non-existent in the intensively farmed karst depressions.

The situation is different on rocky karst slopes, where soil is generally shallow. The natural Mediterranean vegetation on carbonate outcrops consisted mostly of dense forest and maquis. The expansion of settlement in historical times resulted in deforestation which promoted soil degradation. Deforestation took place in several forms: clearing of vegetation for tillage, planned and accidental fires, and cutting timber for construction, industry and fuel. Therefore, deforestation was tightly associated with settlement expansion. After a piece of land was deforested, continuous grazing by goats and sheep inhibited the natural succession and regeneration of the forest even in periods of settlement contraction. Grazing was harmful also to agriculture, especially in years of drought, when nomads from the desert penetrated the cultivated land with their goats. The long dry and hot summers rendered the forests susceptible to fires which occurred either naturally or artificially as means for clearing the land, driving game for hunting, improving pasture for game and domesticated animals, or as an act of war.

According to the Bible, the karst surface north of Jerusalem (or possibly east of the Jordan river) was deforested at the beginning of the Israelite period (4th millennium B.P.) when the tribes of Joseph settled this area because the fertile valleys were already occupied by the Cananites:

"And Joshua said to them: If you are numerous people, go up to the forest, and there clear ground for yourselves... the hill country shall be yours, for though it is a forest, you shall clear it and possess it to its farthest borders" (Joshua 17, 15-18, 
Collins edition).

The Hebrew word 'Ya'ar' used here for a forest to be cleared appears some 50 times in the bible, with apparently two meanings (Tur-Sinai, 1965). Apart from the usual meaning of dense forest, it sometimes means a wild desolated landscape (e.g. Hoshe'a 2,14; Micha 3,12). This meaning is possibly preserved in the Arabic word 'Wa'ar' which means rugged rocky terrain. This word is used today to describe karst terrains common in the late Cretaceous carbonate outcrops of the mountains of Israel. A field survey of the usage of this word indicates that it is used to describe landscapes where soil has been partly or completely stripped from karren fields.

In spite of deforestation, the Bible includes many references to a dense forest over the karst landscape throughout biblical times, indicating that deforestation was not very intensive at that time. Archaeological evidence indicates that population density achieved its climax in the Hellenistic-Roman-Byzantine periods (24-15th century B. P.), associated with large-scale deforestation and agricultural development. Palinological studies in Lake Kinneret and the Dead Sea (Baruch, 1990) also show that during this time the natural forest was replaced by extensive fruit farming, mainly olive plantations. Olive trees were both economically important and well suited for the terra-rossa soil within the karst deforested areas (Fig. 3). Olive presses were excavated during this period not only in the soft chalk of the Shefela lowland region, but also in the hard carbonate rocks of the mountains.

Decline of agriculture and re-establishment of the forest plants occurred during the second half of the second millennium B. P., as indicated by historical, archaeolo-

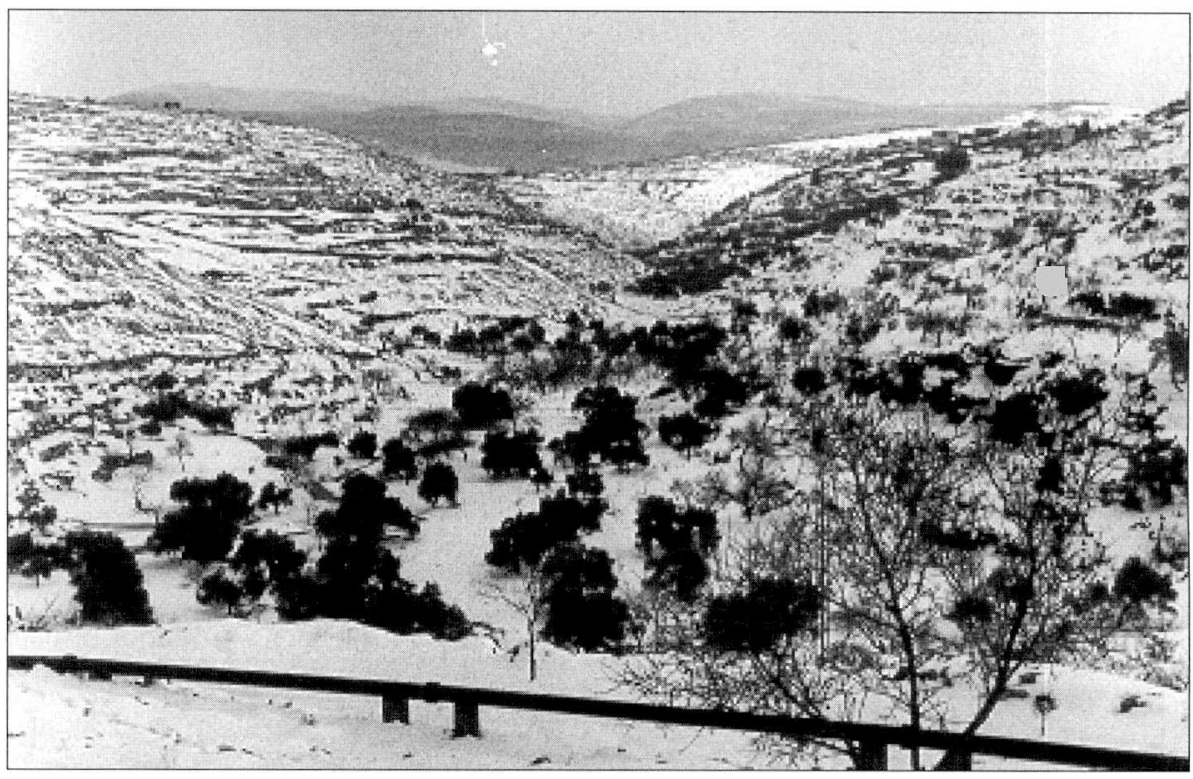

Fig. 3 - Olive groves on deep soils in a fluviokarst valley, and terraces on the adjacent slopes (Shomeron) 
gical and palinological records. Sarcopoterium spinosum was the main early invader into abandoned olive grove areas, followed by forest regeneration (Baruch, 1990). However, the prolonged human interference caused soil degradation and exposure of karstified rocks, so the natural forest did not re-establish itself in the original form and species. Taxa which manage well on rock exposures, such as Quercus calliprinos and Pistacia palaestina, became dominant over karst areas during the last 1500 years. These species are also resistant to fires, cutting, and grazing.

Deforestation increased again during the last 200 years associated with increasing charcoal industry. This culminated at World War I, when the remaining forests were cut for fuelling military trains. Since 1948 the destruction of natural vegetation has stopped in many karst regions, and forests regenerate in areas where deforestation was never complete. Some of these areas were proclaimed nature reserves. HarMeron nature reserve in the Galil mountains is the largest on karst terrains, with large areas of dense forest. Within the forest are doline fields and karst shafts, including the deepest cave of Israel (Frumkin \& Zeidner, 1984). A village located within the reserve boundaries, exerts continuous pressure to increase its cultivated areas on expense of the forest. This pressure included the construction of illegal roads within the reserve and active deforestation. Law enforcing intervention was violently resisted by the inhabitants a few years ago. A compromise was finally reached, but the reserve still suffers damage.

\section{Terracing}

Linear dry field terraces were commonly built in the fluviokarst slopes of Israel. They involve the construction of a stone wall along the hill slope and creation of arable land behind it. This technique was practiced in Israel for at least 3000 years, as indicated by archaeological evidence and the Bible (Cant. 2, 14). Terraces were considered part of the 'normal system', so the prophecy of Ezekiel about total destruction of the mountain landscape includes: "The cliffs shall fall and every terrace shall tumble down" (Ezek. 38,20).

Terraces controlled runoff, reduced soil erosion, and allowed the operation of animal traction

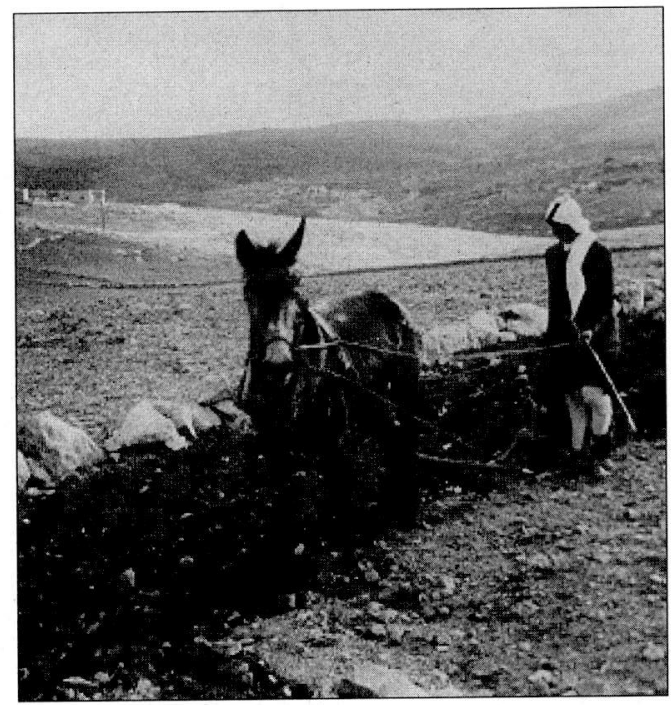

Fig. 4 - Traditional-style plowing along a linear terrace. The terrace and the parallel plowing reduce soil-erosion. plowing (Fig. 4).

They were not level except for artificially irrigated terraces, where absolute level- 
ness was needed for even distribution of water. Terraces served as shelves where soil, minerals, and organic matter could accumulate, while (rainfall or irrigation) water could infiltrate into the ground. This is important in the dry climate of Israel, both for soil water balance and for ground water recharge. Terrace walls also served as a means to dispose of stones collected from the field.

Terraces were built primarily on outcrops of dolomites with intercalations of marls, such as Giv'at Ye'arim, Soreq, and Bet Me'ir formations in the Jerusalem region. These formations assume a natural step-like morphology, so the terrace wall could be based on the hard dolomite layer, and the marl constituted part of the soil behind the terrace wall. The same marl layers inhibit karst water circulation in these formations, and promote subaerial runoff. Therefore, the construction of terraces on these formations was more important than on karstic formations, in terms of water management.

On the other hand, karstic carbonate rocks without marl intercalations, such as the 'Amminadav, Weradim, and Bi'na formations in the Jerusalem region, create a rugged karren topography promoting water infiltration into well-developed fissures and karst conduits. Consequently, terraces are less common on these karstic outcrops. Agriculture was developed in valleys and soil patches within the karren fields of these formations. Stones collected in these fields were used for building fences and watch towers, or just piled over protruding rocks (Fig 5).

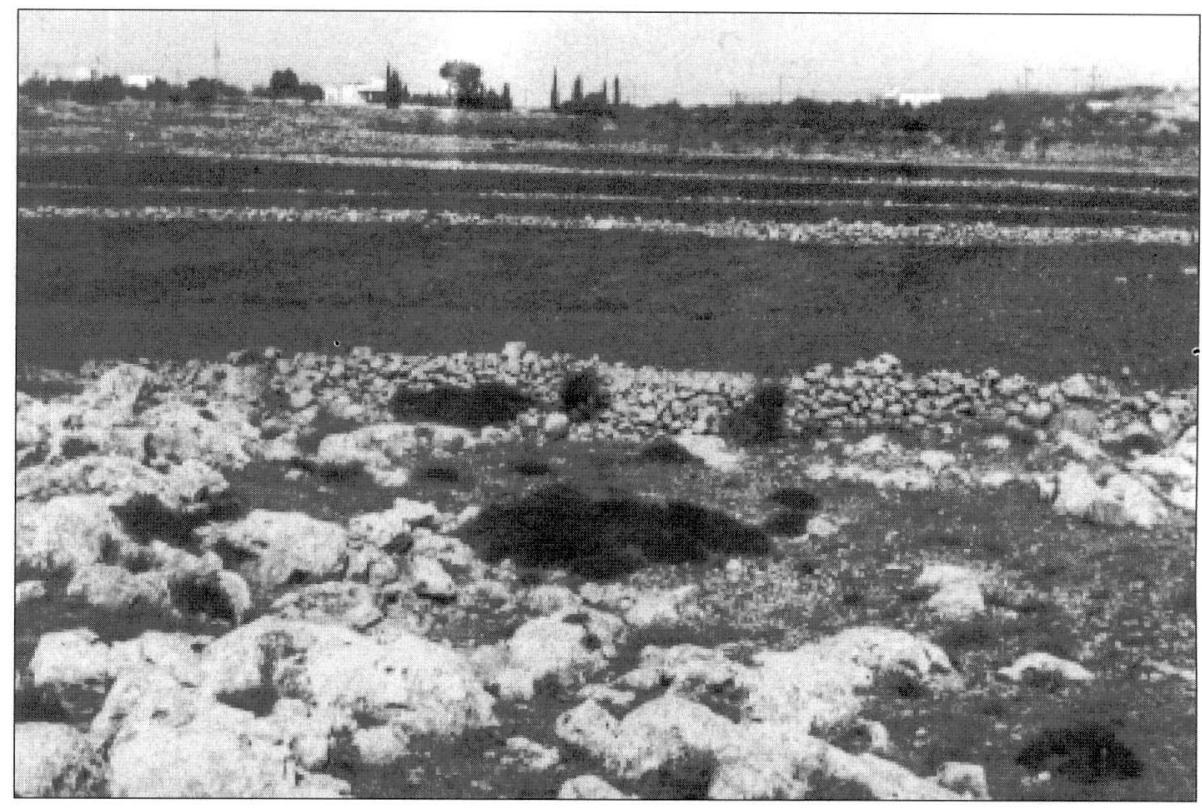

Fig. 5 - Summer view of a karst plateau over 'Amminadav Formation north of Jerusalem: A doline (foreground) where deforestation and agriculture took place in the past was invaded by Sarcopoterium spinosum (dark patches) when cultivation ceased. Wheat cultivation is still practiced at the larger karst depression filled with deep soil (background). 
In some cases intentional erosion of terra rossa pockets in karren fields was induced by farmers, in order to enrich the down-slope terraces with eroded soil. This was done by clearing stones along lines perpendicular to the slope, forming channels for runoff water (Ron, 1966).

The ancient stone wall terraces are carefully built and are therefore labour-intensive. During the last centuries farmers concentrated on repairing old terraces rather than building new ones. Today another kind of terrace is replacing the ancient one. It involves heavy machinery instead of human work, and the terraces are wider, with piles of rocks along the edge of each terrace (Fig. 6).

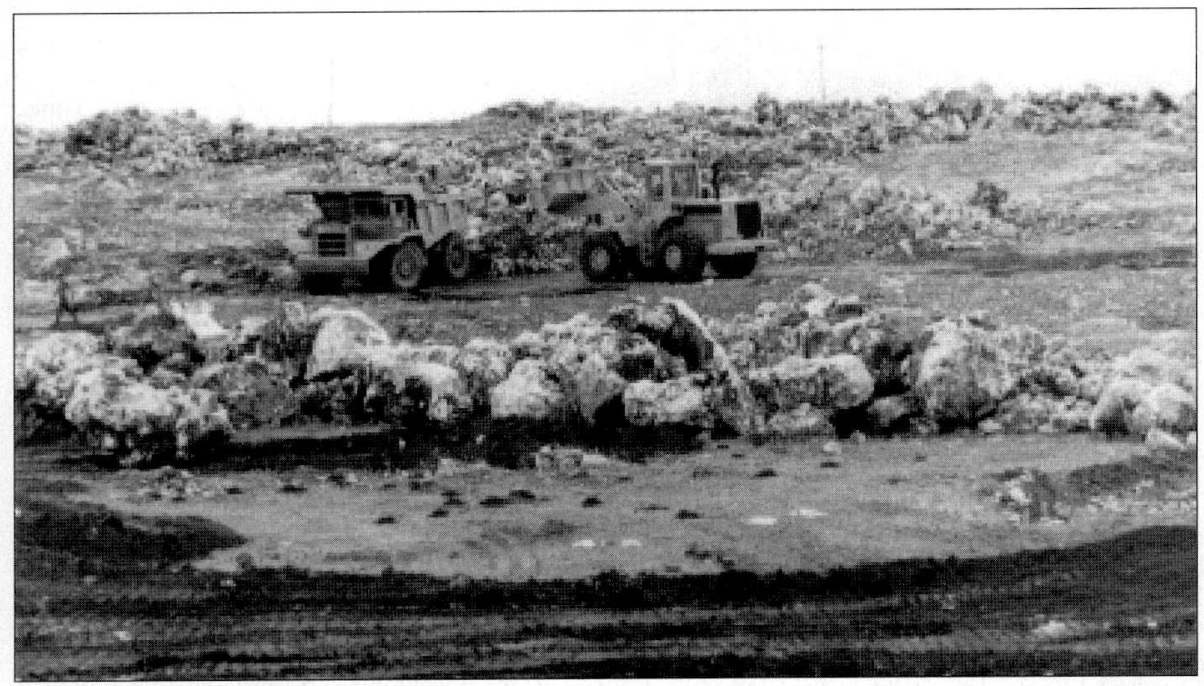

Fig. 6 - Modern development of a karst slope: heavy machinery uproots limestone blocks and transfers them to form arable patches of soil bordered by piles of rocks.

These terraces are built of uprooted stones and rocks cleared by bulldozers from the field surface. This practice is especially effective in karren fields where subsoil and epikarst dissolution detaches the protruding rocks from the underlying bedrock. It is used mainly for growing fruit in the hills of Judea and Galil. However, this type of land use causes some soil erosion over the newly cultivated areas.

\section{Conclusion}

The present karst landscape of Israel is the product of several thousand years of human impact changing the natural environment. Deforestation resulted in increasing erosion rates on karst surfaces, but terracing helped in conservation of soil and water. As water is the most limited resource in this dry region, several engineering solutions were utilized to use the available water in the best way. This included using rain water and ground water, as well as limiting the amount of runoff and increasing the infiltration. 


\section{REFERENCES}

BARUCH U., 1990. Palynological evidence of human impact on the vegetation as recorded in Late Holocene lake sediments in Israel. In: Bottema S., Entjes-Nieborg G., Van-Zeist W. (Eds.), Man's role in shaping of the Eastern Mediterranean landscape. Brookfield, Rotterdam, 283-293.

DAN J., YAALON D. H., KOYUMDJISKY H., RAZ Z., 1976. The soils of Israel (with map 1:500,000). Ministry of Agriculture, Bet Dagan.

FORD D. C., WILLIAMS P.W., 1989. Karst geomorphology and hydrology. Unwin Hyman, London.

FRUMKIN A., 1986. Speleogenesis of vertical shafts in a Mediterranean environment (Ofra, Israel) (abstract). In 9th Congreso International de Espeleologia 1. UIS, Barcelona: 264-267.

FRUMKIN A., 1993. Karst origin of the upper erosion surface in the Northern Judean Mountains, Israel. Israel Journal of Earth Sciences 41: 169-176.

FRUMKIN A., CARMI I., GOPHER A., TSUK T., FORD D. C., SCHWARCZ H. P., 1999. Holocene millennial-scale climatic cycle from Nahal Qanah Cave speleothem, Israel. The Holocene 9(6): 677-682.

FRUMKIN A., CARMI I., ZAK I., MAGARITZ, M., 1994. Middle Holocene environmental change determined from the salt caves of Mount Sedom, Israel. In: Bar- Yosef O., Kra R. (Eds.), Late Quaternary chronology and paleoclimates of the eastern Mediterranean. The University of Arizona, Tucson: 315-322.

FRUMKIN A., MAGARITZ M., CARMI I., ZAK I., 1991. The Holocene climatic record of the salt caves of Mount Sedom, Israel. The Holocene 1(3): 191-200.

FRUMKIN A., ZEIDNER A., 1984. The Jermak "hutta" - Israel deepest cave (Hebrew,

English abstract). Niqrot Zurim, Journal of the Israel Cave Research Center 10: 37-51.

GERSON R., 1974. Karst processes of the eastern Upper Galilee, northern Israel. 21: 131-152. HUNTINGTON H., 1911. Palestine and its transformation. Houghton Mifflin, Boston, New York. ISSAR A. S., 1990. Water from the rock. Springer Verlag, Heidelberg.

ISSAR A. S., GOVRIN Y., GEYH M. A., WAKSHAL E., WOLF M., 1991. Climatic changes during the Upper Holocene in Israel. Israel Journal of Earth Sciences 40: 219-223.

MIRON Y., FRUMKIN A., 1986. Ein Wadi el Biar - the largest spring cave in Israel (in Hebrew). Niqrot Zurim 13: 104-108.

PORATH Y., 1987. Qanats in the Arava (in Hebrew). Qadmoniot 79-80: 106-114.

PRITCHARD J. B., 1961. The water system of Gibeon. The University Museum, Philadelphia.

RON Z., 1966. Agricultural terraces in the Judean Mountains. Israel Exploration Journal 16: 111-116.

SASS E., BEIN A., 1978. Platform carbonates and reefs in the Judean Hills, Carmel and Galilee. In Tenth international congress on sedimentology 2. International Association of sedimentologists, Jerusalem, 239-274.

SIGELMAN A., RAVEK Y., 1993. Ancient water system in Upper Nahal Taninim (Hebrew, English abstract). Niqrot Zurim 19: 27-43.

STEINITZ G., BARTOV Y., 1991. The Miocene-Pliocene history of the Dead Sea segment of the Rift in light of K-Ar ages of basalts. Israel Journal of Earth Sciences 40 (1-4): 199-208.

TSUK T., MIRON Y., WOLOVELSKY K., 1986. Biar aqueduct survey (in Hebrew). Niqrot Zurim 13: 109-129.

TUR-SINAI N. H., 1965. Ya'ar. In Encyclopaedia Biblica. Bialik Institute, Jerusalem, 3: 722-723.

YAALON D. H., GANOR, E., 1973. The influence of dust on soils during the Quaternary. Soil Science 116(3): 146-155. 